\title{
PENINGKATAN MOTIVASI DAN HASIL BELAJAR MATEMATIKA MELALUI MODEL MAKE A MATCH
}

\author{
Dwi Anggraeni Siwi' ${ }^{1)}$; Oktavianur Primastianingrum ${ }^{2)}$ \\ ${ }^{1}$ Pendidikn Guru Sekolah Dasar, UNIVET BANTARA SUKOHARJO \\ deeanggraenny@yahoo.com \\ ${ }^{2}$ Pendidikn Guru Sekolah Dasar, UNIVET BANTARA SUKOHARJO \\ oktavianur@gmail.com
}

\begin{abstract}
Abstrak
Penelitian ini bertujuan untuk: (1) meningkatkan motivasi belajar Matematika melalui model Kooperatif tipe Make a Match pada siswa kelas III SD N 3 Ngreden Kecamatan Wonosari Kabupaten Klaten Tahun Pelajaran 2016/2017, (2) meningkatkan hasil belajar Matematika dengan model pembelajaran Kooperatif tipe Make a Match pada siswa kelas III SD N 3 Ngreden Kecamatan Wonosari Kabupaten Klaten Tahun Pelajaran 2016/2017. Penelitian ini merupakan Penelitian Tindakan Kelas (PTK). Penelitian ini dilaksanakan dalam 2 siklus terdiri atas perencanaan, pelaksanaan tindakan, observasi, dan refleksi. Subjek penelitian adalah guru dan siswa kelas III SD N 3 Ngreden Kecamatan Wonosari Kabupaten Klaten Tahun Pelajaran 2016/2017 yang berjumlah 20 siswa, terdiri dari 10 siswa laki-laki dan 10 siswa perempuan. Teknik pengumpulan data melalui wawancara, obsevasi, tes dan angket. Analisis data menggunakan teknik analisis deskriptif kuantitatif. Hasil penelitian ini menunjukkan (1) persentase hasil motivasi belajar diketahui dari pra siklus terdapat $20 \%$ siswa memiliki motivasi belajar berkategori tinggi dan atau sangat tinggi kemudian pada siklus I meningkat menjadi 50\% dan pada siklus II $80 \%$. Berdasarkan hasil penelitian dan pembahasan Motivasi Belajar dapat disimpulkan bahwa penerapan model pembelajaran Kooperatif tipe Make a Match dapat meningkatkan Motivasi Belajar Siswa. (2) persentase pencapaian ketuntasan hasil belajar Matematika siswa yang semula pada pra siklus adalah $20 \%$ yang mencapai KKM kemudian pada siklus I meningkat menjadi 65\%dan pada siklus II mencapai 95\%. Berdasarkan hasil penelitian dan pembahasan, dapat disimpulkan bahwa penerapan model pembelajaran Kooperatif tipe make a match dapat meningkatkan Hasil Belajar Siswa kelas III SD N 3 Ngreden Kecamatan Wonosari Kabupaten Klaten Tahun Pelajaran 2016/2017.
\end{abstract}

Kata Kunci: motivasi belajar, hasil belajar Matematika, model pembelajaran Kooperatif tipe Make a Match

Abstract
This study aims to: (1) improve the motivation of learning Mathematics through the model
of Cooperative type Make a Match on the third grade students of SD N 3 Ngreden,
Wonosari Sub-district, Klaten Lesson Year 2016/2017, (2) Improving Mathematics
Learning Outcomes with Cooperative Learning Model Type Make a Match on third grade
students of SD N 3 Ngreden Sub Wonosari Sub-district of Klaten Lesson Year 2016/2017.
This research is a Classroom Action Research (PTK). This research was conducted in 2 
cycles consisting of planning, implementation of action, observation, and reflection. The subjects of the study were teachers and third grade students of SD N 3 Ngreden Wonosari Sub-district, Klaten Regency of 2016/2017 which consisted of 20 students consisting of 10 male students and 10 female students. Technique of collecting data through interview, obsevasi, tes and enquette. Data analysis using quantitative descriptive analysis technique. The results of this study indicate (1) the percentage of learning motivation outcomes is known from the pre cycle there are $20 \%$ of students have high learning motivation and / or very high then in the first cycle increased to $50 \%$ and on the second cycle $80 \%$. Based on the results of research and discussion of Learning Motivation can be concluded that the implementation of cooperative model type Make a Match can improve Student Motivation. (2) the percentage of mathematics learning achievement achievement of the original students in the pre cycle is $20 \%$ reaching KKM then in the first cycle increased to $65 \%$ and in the second cycle reached $95 \%$. Based on the results of research and discussion, it can be concluded that the implementation of cooperative learning model type make a match can improve Student Results class III SD N 3 Ngreden District Wonosari Klaten District Lessons 2016/2017.

Kay Word : Motivation to learn, mathematics learning outcomes, cooperative learning model type Make a Match

\section{PENDAHULUAN}

Pendidikan pada dasarnya suatu proses untuk membantu manusia dalam mengembangkan dirinya, sehingga mampu menghadapi segala perubahandan permasalahan dengan sikap terbukaserta pendekatan-pendekatan yang kreatif tanpa harus kehilangan identitas dirinya. Sekolah merupakan bagian dari sistem pendidikan formal yang mempunyai aturan-aturan jelas. Oleh karena itu seorang Guru harus mampu menjalankan peranannya sebagai seorang pendidik dan mampu mengoptimalkan kompetensinya, Maka Guru sebagai fasilitator yang berperan dalam keberhasilan siswa atau peserta didik. Untuk itu, guru harus tepat dalam memilih metode pembelajaran yang akan digunakan agar hasil belajarnya tercapai.

Menurut Slameto (2003:2) Belajar ialah suatu proses usaha yang dilakukan seseorang untuk memperoleh suatu perubahan tingkah laku yang baru secara keseluruhan, sebagai hsul pengalamannya sendiri dalam interaksi dengan lingkungannya. Hasil belajar dapat tercapai apabila guru dalam menyampaikan pelajaran tidak menjadikan siswa hanya sebagai obyek belajar, tetapi siswa dijadikan sebagai subyek, sehingga siswa bisa terlibat langsung dalam proses pembelajaran. Selain itu juga, guru tidak hanya menggunakan model pembelajaran 
yang monoton tetapi, guru harus bisa mengembangkan model pembelajaran yang bervariasi dan dapat meningkatkan hasil belajar siswa.

Sekolah Dasar Negeri 3 Ngreden terletak di Kabupaten Klaten tepatnya di kecamatan Wonosari, Adapun letak kelas III yang dijadikan subyek dalam Penelitian ada kompleks SD bagian selatan. Ruang kelas III menghadap ke sebelah utara dengan papan tulis untuk aktifitas mengajar menghadap ke barat. Jumlah siswa kelas III sebanyak 20 siswa dengan siswa laki-laki 10 siswa dan siswa perempuan 10 siswa.

Berdasarkan hasil wawancara dengan guru kelasIII SD N 3 Ngreden Kecamatan Wonosari Kabupaten Klaten diperoleh informasi bahwa motivasi siswa dalam proses pembelajaran Matematika memang kurang. Meskipun dalam proses pembelajaran guru sudah menggunakan model ataupun media pembelajaran yang dapat membantu siswa, akan tetapi model atau media yang digunakan masih kurang inovatif sehingga siswa merasa bosan dan mengakibatkan motivasi dan hasil belajar siswa rendah. Hal tersebut dapat dilihat dari kurang fokusnya siswa dalam kegiatan pembelajaran dan cenderung sibuk dengan kegiatan yang tidak ada hubungannya dengan proses pembelajaran seperti melamun, bermain dengan teman sebangkunya, meletakan kepala di atas meja, jarang bertanya pada guru meskipun belum paham materi, tidak berani mengemukakan pendapat dan lain-lainnya. Menurut Ismail (2011:160) Matematika adalah merupakan ide-ide yang bersifat abstrak, dengan struktur-struktur deduktif, mempunyai peran yang penting dalam pengembangan ilmu pengetahuan dan teknologi. Ketidak tuntasan nilai hasil belajar tersebut dikarenakan guru belum menggunakan model pembelajaran yang dapat menumbuhkan motivasi belajar siswa.

Dalam mengatasi masalah diatas, perlu diupayakan suatu pendekatan pembelajaran yang dapat digunakan agar siswa lebih aktif dalam pembelajaran sehingga membuat hasil belajar siswa meningkat. Salah satu cara yang dapat ditempuh adalah dengan menerapkan Pendekatan Pembelajaran Kooperatif dan Memberikan Motivasi pada anak untuk tidak takut dalam menghadapi pelajaran 
matematika, karena pelajaran matematika itu tidak perlu untuk ditakuti karena pelajaran ini merupakan pelajaran yang menyenangkan.

Berdasarkan uraian di atas tujuan yang akan dicapai dalam penelitian adalah 1)untuk meningkatkan Motivasibelajar Matematika melalui model kooperatifTipe Make a MatchPada Siswa Kelas III SD Negeri 3 Ngreden Wonosari Klaten 2016/2017; 2)untuk meningkatkan Hasil Belajar Matematika melalui model kooperatif tipe make a match pada siswa kelas III SD N 3 Ngreden Klaten tahun pelajaran 2016/2017.

\section{METODE PENELITIAN}

Penelitian ini menggunakan jenis Penelitian Tindakan Kelas. Penelitian ini merupakan penelitian tindakan kelas yang dilakukan untuk meningkatkan motivasi dan hasil belajar Matematika kelas III SD N 3 Ngreden Wonosari Klaten. Penelitian ini merupakan Penelitian Tindakan Kelas karena ingin memecahkan masalah yang terjadi di kelas. Langkah-langkah penelitian tindakan kelas adalah sebagai berikut ini:

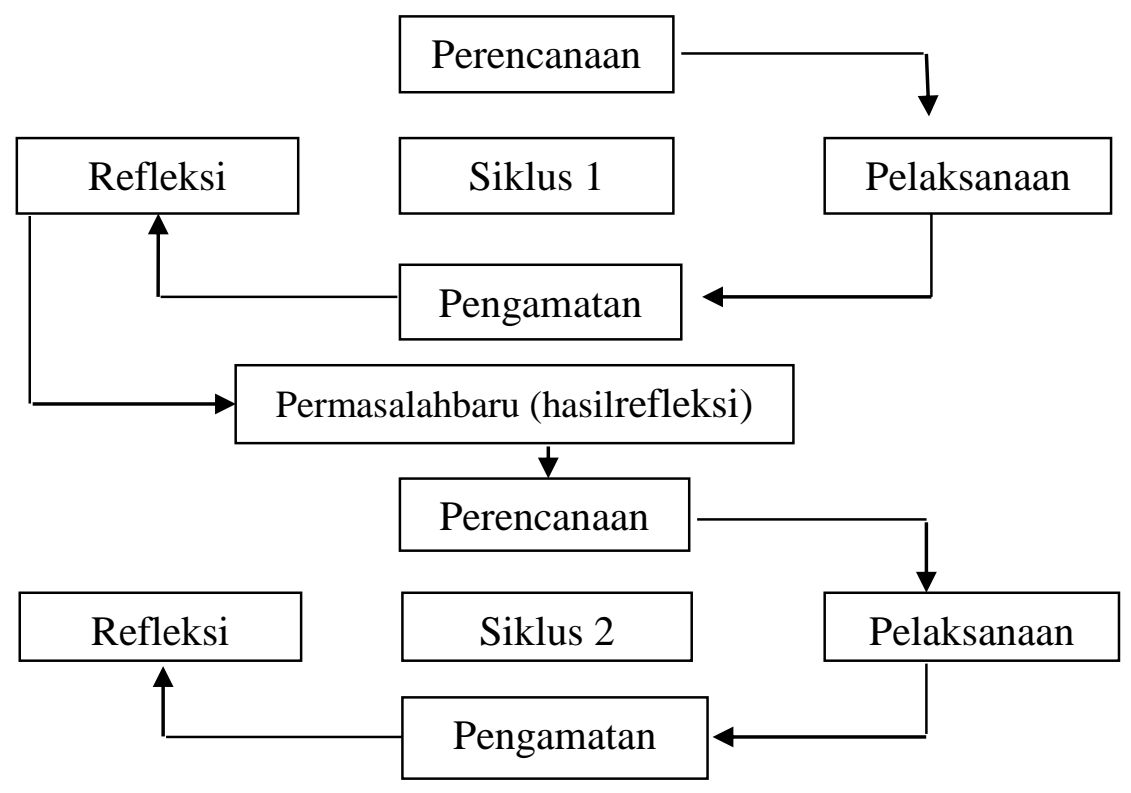

Gambar 1.Siklus Penelitian 
Penelitian ini dilakukan di Sekolah Dasar Negeri 3 Ngreden kecamatan Wonosari kabupaten Klaten. Subjek dalam penelitian ini adalah siswa dan guru kelas III SD N 3 Ngreden kecamatan Wonosari kabupaten Klaten yang berjumlah 20 siswa, terdiri dari 10 siswa laki-laki dan 10 siswa perempuan. Sedangkan objek penelitian dari penelitian ini adalah Motivasi dan Hasil Belajar Matematika kelas III SD N 3 Ngreden kecamatan Wonosari kabupaten Klaten Tahun Ajaran 2016/2017.

Teknik pengumpulan data bertujuan untuk mempermudah peneliti untuk memperoleh data yang di perlukan dalam penelitian. Adapun tehnik pengumpulan data dilakukan adalah 1)Wawancara; 2)Observasi; 3)Tes; 4)Angket. Teknik analisis data pada penelitian ini adalah deskriptif kuantitatif.

Sedangkan indikator keberhasilan merupakan tolak ukur keberhasilan penelitian yang dilakukan dalam penelitian ini. Indikator keberhasilan pada penelitian tindakan kelas adalah 1)Jika dalam kegiatan belajar mengaja $r \geq 70 \%$ dari jumlah siswa yaitu 20 siswa mampu memperoleh nilai di atas atau sama dengan KKM mata pelajaran Matematika yang ditentukan yaitu 64. 2)Banyaknya siswa yang memiliki motivasi belajar kategori tinggi dan atau sangat tinggi adalah $\geq 70 \%$ dari jumlah seluruh kelas III yaitu 20.

Untuk menjamin dan mengembangkan penelitian, validitas data yang akan dikumpulkan dalam penelitian, teknik pengembangan validitas data yang digunakan adalah teknik triangulasi. Dalam penelitian ini, validitas yang dilakukan adalah pengamatan langsung pada aktivitas siswa dan dokumentasi keadaan siswa di dalam kelas yang berupa daftar nilai. 


\section{HASIL DAN PEMBAHASAN}

\section{a. HASIL PENELITIAN}

1.) Deskripsi Kondisi Awal

a.) Motivasi

Peneliti membagikan angket motivasi belajar kepada siswa untuk mengetahui tingkat motivasi siswa dalam mengikuti pembelajaran Matematika. Dari pembagian angket tersebut dapat diketahui bahwa siswa yang memiliki motivasi belajar tinggi sebanyak 4 siswa (20\% dari jumlah siswa kelas), siswa yang memiliki motivasi belajar sedang sebanyak 10 siswa (50\% dari jumlah siswa kelas) dan siswa yang memiliki motivasi belajar rendah sebanyak 6 siswa (30\% dari jumlah siswa di kelas) dengan rata-rata skor motivasi belajar 43. Berikut tabel motivasi belajar pada kondisi awal/pra siklus

Tabel 1. Hasil Motivasi Belajar Siswa Pra siklus

\begin{tabular}{rccc}
\hline Keterangan & Pra siklus & Siklus I & Siklus II \\
\hline Nilai rata-rata & 43 & 58 & 75 \\
Nilai tertinggi & 62,5 & 82,5 & 97,5 \\
Nilai terendah & 32,5 & 40 & 40 \\
Persentase ketuntasan & $20 \%$ & $50 \%$ & $80 \%$ \\
\hline
\end{tabular}

Dari hasil pelaksanan siklus I diketahui motivasi belajar siswa mengalami peningkatan yang sebelum pra tindakan hanya 4 siswa $(20 \%)$ memiliki motivasi belajar berkategori tinggi dan atau sangat tinggi pada siklus I meningkat menjadi 10 siswa (50\%). Hasil siklus II dapat diketahui bahwa perolehan hasil motivasi belajar siswa yang telah mencapai target indikator keberhasilan yakni $\geq 70 \%$ (minimal 13 siswa) dari jumlah seluruh kelas III yaitu 16 memiliki motivasi belajar berkategori tinggi dan atau sangat tinggi. Berdasarkan tabel1 tersebut dapat diketahui 16 siswa yang memiliki motivasi belajar berkategori tinggi/sangat tinggi (80\% dari jumlah siswa di kelas), 3 siswa yang memiliki motivasi belajar berkategori sedang (15\% dari 
jumlah siswa) dan 1 siswa yang memiliki motivasi belajar yang berkategori rendah dengan skor rata-rata 75 .

b.) Hasil Belajar

Belajar siswa yang memperoleh nilai di bawah Kriteria Ketuntasan Minimal (KKM), yaitu 64. Dari 20 siswa, hanya terdapat 4 siswa mendapatkan nilai ulangan diatas KKM (20\% dari jumlah siswa di kelas) dan terdapat 16 siswa yang mendapatkan nilai ulangan dibawah KKM (80\% dari jumlah siswa di kelas). Berikut ini tabel perolehan ketuntasan hasil belajar Matematika pada kondisi awal pra siklus :

Tabel 2. Hasil belajar Matematika Pra siklus

\begin{tabular}{rccc}
\hline Keterangan & Pra siklus & Siklus I & Siklus II \\
\hline Nilai rata-rata & 62.5 & 69 & 89 \\
Nilai tertinggi & 80 & 80 & 100 \\
Nilai terendah & 50 & 60 & 60 \\
Persentase ketuntasan & $20 \%$ & $65 \%$ & $95 \%$ \\
\hline
\end{tabular}

Semula pada pra tindakan adalah 20\% (4 siswa) dengan rata-rata 62,5 kemudian pada siklus I mencapai 65\% (13 siswa) dengan rata-rata 69 dan pada siklus II mencapai 95\% ( 19 siswa) dengan rata-rata 89 dengan peningkatan rata-rata hasil belajar sebesar 20. Hal ini sesuai dengan apa yang dikemukakan oleh Sadirman (2014:85) bahwa dengan adanya motivasi belajar yang baik akan menujukan hasil belajar yang baik.

Berdasarkan hasil siklus II tersebut dapat diketahui bahwa 19 siswa ( 95\% dari jumlah siswa) telah mencapai KKM dan 1 siswa (5\% dari jumlah siswa di kelas) tidak mencapai KKM dengan rata-rata nilai 89.

\section{b. PEMBAHASAN}

Ketika hendak melaksanakan siklus I, peneliti melakukan wawancara dengan guru kelas untuk mengetahui kondisi awal yang terjadi di lapangan. Dari hasil wawancara, diperoleh informasi bahwa motivasi siswa dalam proses pembelajaran Matematika memang kurang. Meskipun dalam proses 
pembelajaran guru sudah menggunakan model ataupun media pembelajaran yang dapat membantu siswa, akan tetapi model atau media yang digunakan masih kurang inovatif sehingga siswa merasa bosan dan mengakibatkan motivasi dan hasil belajar siswa rendah.

Hal tersebut dapat dilihat dari kurang fokusnya siswa dalam kegiatan pembelajaran dan cederung sibuk dengan kegiatan yang tidak ada hubungannya dengan proses pembelajaran seperti melamun, bermain dengan teman sebangkunya, meletakan kepala di atas meja, jarang bertanya pada guru meskipun belum paham materi, tidak berani mengemukakan pendapat dan lain-lainnya.

Dengan penerapan model pembelajaran Kooperatif tipe make a match, siswa diberikan kesempatan untuk berpartisipasi dalam kegiatan pembelajaran. Dalam proses pembelajaran lebih menekankan pada pengalaman langsung siswa dengan memberikan kesempatan pada siswa menemukan sendiri konsep-konsep pembelajaran.Model pembelajaran Kooperatif tipe make a match dirancang dengan memberikan suatu masalah kepada siswa kemudian siswa diberikan kesempatan untuk memecahkan masalah tersebut untuk menemukan sendiri konsep-konsep pembelajaran yang telah dipelajari. Siswa benar-benar ditempatkan sebagai subjek belajar sedangkan peran guru dalam model pembelajaran ini adalah sebagai pembimbing belajar dan fasilitator belajar. Proses pembelajaran yang seperti ini dapat menumbuhkan motivasi belajar yang lebih pada siswa.

Hasil penelitian yang dilakukan pada pelaksanaan pembelajaran Matematika di kelas III SD N 3 Ngreden Kecamatan Wonosari Kabupaten Klaten dengan menerapkan model pembelajaran Kooperatif tipe Make a Matchmenunjukan bahwa pelaksanaan pada setiap siklus penelitian mengalami peningkatan pada tiap siklusnya. Peningkatan terlihat dari siklus I dan siklus II, yang disajikan sebagai berikut :

1.) Peningkatan Motivasi 
Dari hasil pelaksanaan siklus I diketahui motivasi belajar siswa mengalami peningkatan yang sebelum pra tindakan hanya 4 siswa $(20 \%)$ memiliki motivasi belajar berkategori tinggi atau sangat tinggi pada siklus I menjadi 10 siswa $(50 \%)$. peningkatan skor rata-rata motivasi belajar Matematika yang semula pada pra tindakan 43 kemudian pada siklus I peningkatan skor rata-rata menjadi 58.

Dari pelaksanaan siklus II dapat diketahui bahwa perolehan hasil motivasi belajar siswa yang telah mencapai target indikator keberhasilan yakni $\geq 70 \%$ (minimal 13 siswa) dari jumlah siswa seluruh kelas III yaitu 16 memiliki motivasi belajar berkategori tinggi/sangat tinggi. Pada pra tindakan hanya 4 siswa (20\%) memiliki motivasi belajar berkategori tinggi atau sangat tinggi, kemudian pada siklus I meningkat menjadi 10 siswa (50\%) dan pada siklus II meningkat menjadi 16 siswa (80\%) memiliki motivasi belajar berkategori tinggi atau sangat tinggi. Peningkatan skor rata-rata motivasi belajar Matematika yang semula pada pra tindakan adalah 43 kemudian siklus I 58 dan siklus II menjadi 75 dengan peningkatan skor rata-rata motivasi belajar sebesar 15 dan 17.

Untuk memperjelas, berikut ini disajikan diagram batang persentase perbandingan motivasi belajar pra siklus, siklus I dan siklus II : 


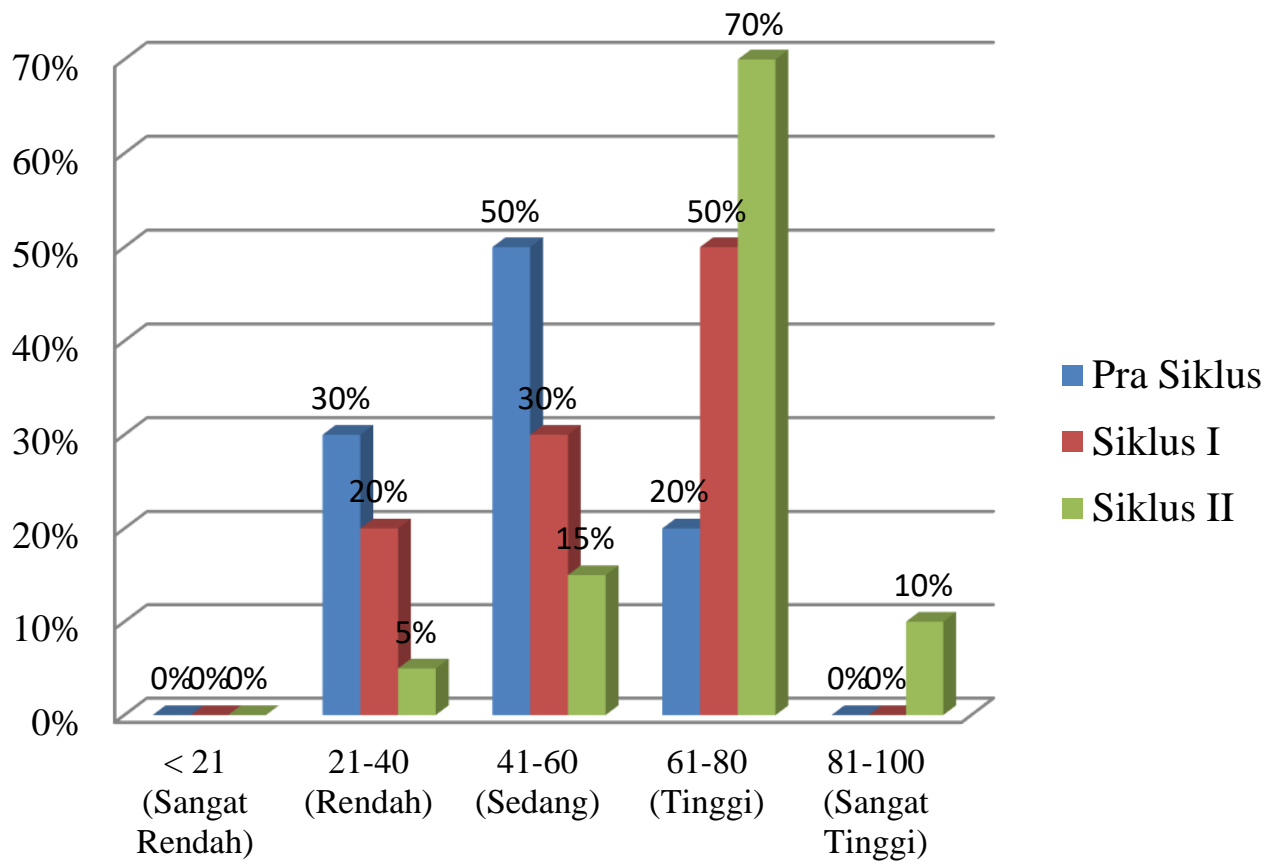

Gambar 2. Perbandingan Persentase Motivasi Belajar Matematika Siswa Pada Pra Siklus, Siklus I dan Siklus II

2.) Peningkatan Hasil Belajar

Persentase ketuntasan hasil belajar siswa juga mengalami peningkatan yang semula pada pra tindakan adalah 4 siswa (20\%) dengan rata-rata 62,5 kemudian pada siklus I mencapai 13 siswa (65\%) dengan ratarata 69 dengan peningkatan rata-rata hasil belajar 6,5.

Dari hasil pelaksanaan siklus II meningkatkan hasil belajar Matematika siswa kelas III SD N 3 Ngreden Kecamatan Wonosari Kabaupaten Klaten. Terlihat dari persentase ketuntasan hasil belajar Matematika siswa yang telah mencapai indikator keberhasilan yakni $\geq 70 \%$ dari jumlah siswa yaitu 19 siswa mampu memperoleh nilai di atas atau sama dengan mata pelajaran Matematika yang di tentukan yaitu 64. Semula pada pra tindakan adalah 4 siswa (20\%) dengan rata-rata 62,5 kemudian pada siklus I mencapai 13 siswa (65\%) dengan rata-rata 69 dan pada siklus II mencapai 19 siswa ( $95 \%$ ) dengan rata-rata 89 dengan peningkatan rata-rata hasil belajar sebesar 20. Hal ini sesuai dengan apa yang dikemukakan oleh 
Sadirman (2-14:85) bahwa dengan adanya motivasi belajar yang baik akan menunjukan hasil belajar yang baik.

Untuk memperjelas, berikut ini disajikan diagram batang persentase perbandingan hasil belajar Matematika siswa pra siklus, siklus I dan siklus II

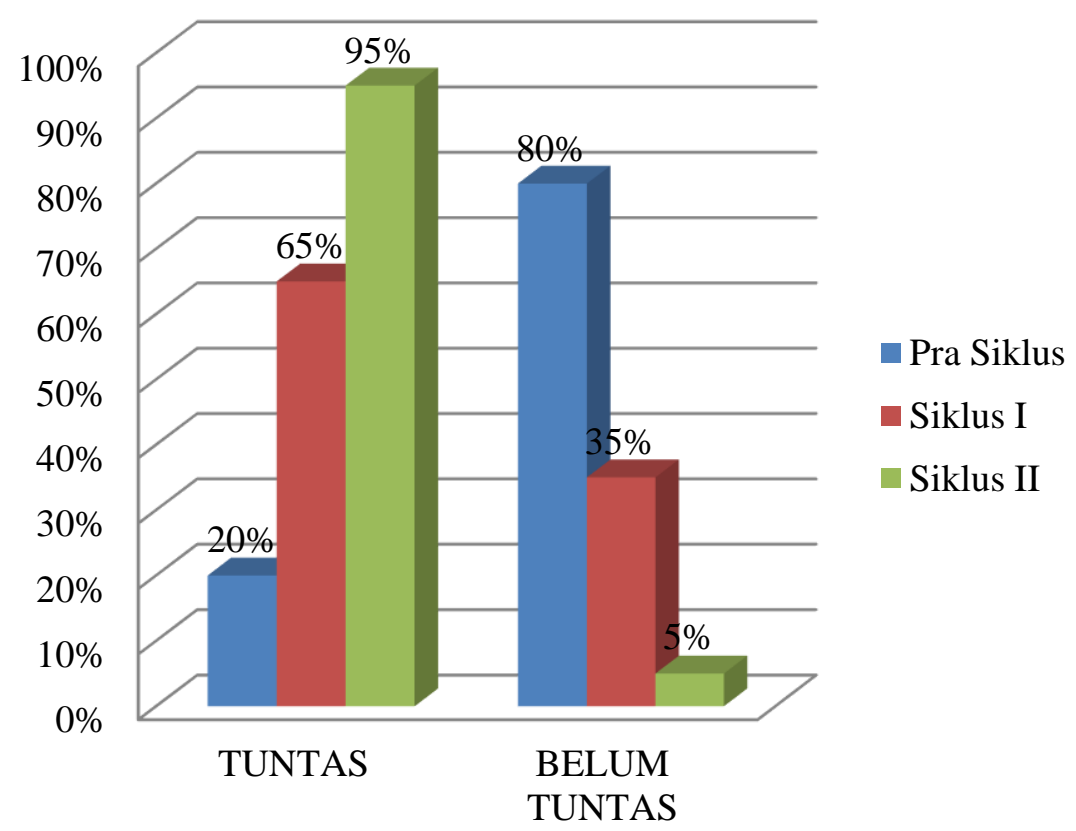

Gambar 3. Perbandingan Persentase Ketuntasan Hasil Belajar Matematika Siswa Pada Pra Siklus, Siklus I dan Siklus II

\section{SIMPULAN}

Berdasarkan hasil penelitian dan pembahasan, dapat disimpulkan bahwa adanya penerapan model pembelajaran Kooperatif tipe Make a Match; 1.) dapat meningkatkan motivasi belajar siswa kelas III SD N 3 Ngreden Kecamatan Wonosari Kabupaten Klaten Tahun Pelajaran 2016/2017. 2.) Dapat meningkatkan hasil belajar siswa kelas III SD N 3 Ngreden Kecamatan Wonosari Kabupaten Klaten Tahun Pelajaran 2016/2017 


\section{REFERENSI}

Fathurrohman,Pupuh.dkk. 2007. Strategi Belajar Mengajar. Bandung : PT Refika Aditama.

Heruman. 2014. Model Pembelajaran Matematika di Sekolah Dasar. Bandung : Remaja Rosdakarya.

Huda,Miftahul. 2013. Model-model Pembelajaran dan Pembelajaran. Yogyakarta: Pustaka Pelajar.

Ismail.2011. Penelitian Pendidikan. Sukoharjo : Univet Bantara Press.

Majid,Abdul. 2014. Strategi Pembelajaran. Bandung: PT Remaja Rosdakarya.

Rusman. 2013. Model-model Pembelajara: mengembangkan profesionalisme guru. Jakarta: Rajawali Pers

Sani Abdullah Ridwan, 2013. Inovasi Pembelajaran. Jakarta : Bumi Aksara.

Sadiman, Arief S.dkk. 2009. MEDIA PENDIDIKAN Pengertian, Pengembangan dan Pemanfaatan. Jakarta :PT Rajagrafindo Persada.

Slameto, 2003. Belajar dan faktor-faktor yang mempengaruhinya. Jakarta: PT Rineka Cipta.

Sugiyono, 2015. Metode Penelitian Pendidikan. Bandung: Alfabet

Suprijono,Agus. 2011. Cooperative Learning Teori dan Aplikasi PAIKEM. Yogyakarta : Pustaka Pelajar.

Susanto, Ahmad. 2013. Teori Belajar dan Pembelajaran di Sekolah Dasar. Jakarta : Praneda Media Grup.

Widayoko, Eko Putro.2015.Evaluasi Program Pembelajaran. Yogyakarta: Pustaka Belajar Yogyakarta Fakultas UIN Sunan Kalijaga Yogyakarta 